\title{
Institutional wage-setting, labour demand and labour supply: causal estimates from a South African pseudo- panel
}

\author{
DIETER VON FINTEL
}

\section{Stellenbosch Economic Working Papers: 07/16}

\author{
KEYWORDS: SOUTH AFRICA; WAGE-UNEMPLOYMENT ELASTICITY; \\ PSEUDOPANEL; UNIONS; FIRM STRUCTURE \\ JEL: J31; J51; C21
}

DIETER VON FINTEL

DEPARTMENT OF ECONOMICS

UNIVERSITY OF STELLENBOSCH

PRIVATE BAG X1, 7602

MATIELAND, SOUTH AFRICA

E-MAIL: DIETER2@SUN.AC.ZA

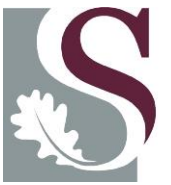

UNIVERSITEIT 


\title{
Institutional wage-setting, labour demand and labour supply: causal estimates from a South African pseudo-panel
}

\author{
Dieter von Fintel ${ }^{1 ; 2}$
}

\begin{abstract}
Unemployment in South Africa has been attributed to multiple causes. Wages have grown faster than productivity to reduce labour demand; demographic shifts have increased labour supply. This paper uses a district pseudo-panel, constructed from household surveys, to estimate the elasticity of labour demand, labour supply and unemployment with respect to wages. The goal is to assess whether hiring decisions are more sensitive to increases in wages of low paid workers than high paid workers, and whether wage growth prompts entry into the labour market. Each of these channels combine to result in the positive causal effect of wage growth on unemployment. Furthermore, the research investigates whether these effects are dominated by districts in which unionization rates are high, and where workers are employed by large firms. In so doing, we quantify the role that institutional wage-setting has in raising wages (which in turn contribute to unemployment). The results illustrate that wages of middle to highly paid workers - as opposed to low paid workers lead to depressed local labour demand and higher local unemployment; these effects can be explained by cross-district unionization rates and the distribution of large firms. Bargaining arrangements correspond closely to the spatial wage distribution; in turn, a large part of the impact that wage growth has on labour market outcomes is determined by these wage-setting institutions.
\end{abstract}

JEL Codes: J31; J51; C21

Keywords: South Africa; wage-unemployment elasticity; pseudopanel; unions; firm structure

\section{Introduction}

High unemployment in South Africa has been attributed to various contributing factors: rising labour supply, structural economic changes (and accompanying skills shortages) and high labour costs have all been cited as

\footnotetext{
${ }^{1}$ Department of Economics, Stellenbosch University; Institute for the Study of Labour (IZA), Bonn; dieter2@sun.ac.za

${ }^{2}$ The author gratefully acknowledges funding for this research from the Research Project on Employment, Income Distribution and Inclusive Growth (REDI3x3). This research was first published as REDI3x3 Working Paper 13. Opinions expressed by the author do not necessarily reflect those of REDI3x3.
} 
constraints to eliminating a long job queue (Banerjee et al., 2008; Bhorat \& Hodge, 1999; Casale \& Posel, 2002; Behar, 2010). The last reason is a point of contention: sectoral and firm-level estimates show that labour demand is highly sensitive to rising labour costs (Behar, 2010; Fedderke, 2012) and, the converse, wage demands do not respond to high local unemployment rates in the short-run (von Fintel, 2015); on the other hand wages do adjust to local labour market conditions in the long-run, while other studies contend that high wage demands and industrial action are not out of line with respect to other relatively low unemployment economies (Bhorat et al., 2014). The recent implementation of a youth wage subsidy is a policy that specifically targets firms' unwillingness to hire seemingly expensive young workers, and has shown to be promising in its success in experimental settings (Levinsohn et al., 2014), but less so after the policy's immediate implementation in the broader labour market (Ranchhod \& Finn, 2014). This too suggests that the cost of labour may be one binding constraint on job creation in South Africa. Furthermore, in light of the discussion around the implementation of a national minimum wage, the political economy debate weighs up the imperative of achieving living wages for workers against employment losses due to higher wages, coupled with a possible increase in the capital intensity of production.

This research re-examines the question of the sensitivity of the labour market to wages, but turns to a household (as opposed to a sectoral or firm) perspective. It estimates wage-employment elasticities and then extends this to measure the sensitivity of participation in the labour market and, ultimately, unemployment to rising labour costs. Furthermore, the use of household data enables this analysis to be estimated in a way that distinguishes the influence of the demands of high wage and low wage workers on unemployment. Should labour demand be sensitive to increases in the wages of the best-paid workers only, it is likely that legislation such as national minimum wages will not increase the unemployment rate to a large degree. The opposite proposition is naturally also equally possible, with elastic labour demand in response to changes in wages of low-paid workers 
potentially triggering great disemployment effects with the implementation of national minimum wages.

This paper estimates dynamic panel data models to account for the possible existence of bi-directional causality between wages and other labour market outcomes $^{3}$, and also for unobservable region-specific conditions (which von Fintel (2015) shows to be important in separating long-run from short-run labour market relationships). We investigate whether the importance of labour supply growth in driving unemployment in South Africa occurs through the pull of better monetary incentives, or whether the dominant accepted causality - namely that high wage demands depress employment creation suffices to explain the role that labour costs have in contributing to unemployment. It furthermore investigates whether institutionalized wagesetting arrangements, such as working in highly unionized districts or those with high concentrations of large firms, can account for the transmission of wage growth to higher unemployment.

The next section of this paper briefly considers the relationship between wages and other labour market outcomes, while section 3 outlines the estimation strategy using household pseudopanel data. Section 4 discusses results, while section 5 concludes.

\section{Causal chains between wages and unemployment}

Separate strands of literature attribute the rise in post-apartheid unemployment to various sources. Some authors focus on the effects that high labour costs have on limiting labour demand (Magruder, 2012; Klein, 2012; Fedderke, 2012) and which lead to the substitution of labour with capital (Behar, 2010). Wages are the central concern. On the other hand, it is now

\footnotetext{
${ }^{3}$ Wage demands can be both the outcome of and a contributor to unemployment. In the first instance, high local unemployment rates generally result in lower wage bargaining power and wage demands. In the second instance, wages that exceed the value of marginal productivity reduce labour demand.
} 
well documented that large increases in labour force participation (supply side) is a defining feature of South Africa's unemployment trajectory since 1994 (Burger \& von Fintel, 2014; Banerjee et al., 2008; Branson \& Wittenberg, 2007). The reasons for this demographic shift are often external to the labour market, including changing household formation patterns, increases in educational attainment and shocks to school enrolment policies (Casale \& Posel, 2002; Burger et al., 2015). Yet, the potential influence that rising wages have on motivating individuals to enter the labour force is not yet well-understood in South Africa; additionally, the channel of rising wages' effect on unemployment by increasing labour supply (as opposed to limiting employment) has not been explored.

If markets were to behave in a Walrasian fashion, wages would fall in order to clear surplus labour and eliminate unemployment (excluding frictional unemployment), while they would rise if labour shortages existed. However, in most instances wages are sticky downwards and unemployment is above zero (Altonji \& Devereux, 1999; Barattieri et al., 2014). Structural unemployment entails that simultaneous labour shortages and surpluses can exist (but of different types of workers), with wage adjustments not being able to eliminate the long-run imbalances in the labour market (Bhorat \& Hodge, 1999). In particular, highly skilled workers are in excess demand, while less skilled workers are in excess supply. In this context, wage increases of highly skilled workers may be coupled with small or zero disemployment effects; in contrast, the capacity to increase the remuneration of unskilled workers is either limited, or accommodated with job loss.

Time series statistics since the 1970s suggest that higher unskilled wages correspond with rising unemployment until 2000, and that a sluggish demand for this type of worker has emerged, while better skilled workers have not faced the same difficulties (Lewis, 2001). However, it is also possible that an equilibrium has emerged in which the labour market has favoured the creation of high skill jobs at a wage premium, at the expense of the creation of unskilled work. This represents a substitution of labour types not necessarily 
because of cost, but because of a structural and/or sectoral shift in the product market (Bhorat \& Hodge, 1999). This study will, therefore, differentiate between wage escalations of highly paid and poorly paid workers to assess the heterogeneous effects of wages on unemployment. In particular, we will study whether a new pattern has emerged, by which high unionization rates at the middle to top of the distribution (as opposed to the bottom of the distribution) has changed the character of the wage-employment relationship in the post-apartheid period.

Despite these deviations from Walrasian theory, wages are nevertheless a mediating factor in regulating the labour market, and their actual relationship to labour demand and supply remains of interest in every context (Fedderke 2012, Klein 2012). However, the relationship between wage demands and other labour market outcomes is complex, and requires careful attention in isolating the role of wage-setting in influencing the rest of the labour market.

The rest of this section briefly considers the labour demand and supply channels through which wages potentially contribute to unemployment, along with the empirical considerations in identifying these channels.

\subsection{Wages and labour demand}

Wages and employment - and thus unemployment rates - are bi-directionally related, with each causal chain highlighting different features of how the labour market functions. Each involves the degree of bargaining that is possible. In the first instance, the wage curve literature (for instance) posits that wages depend on the slackness of local labour market conditions: high regional unemployment lengthens the job queue and, as a consequence, reduces the wage bargaining power of employees (Blanchflower \& Oswald, 1990; Blanchflower \& Oswald, 2008). Testing the validity of this line of causality for South Africa's labour market was the objective of earlier work by von Fintel (2015). Where worker bargaining power is nevertheless able to 
become manifest in high unemployment regions - through institutions such as unionisation and centralized collective bargaining - the impact of local labour market conditions is muted and the wage curve relationship is often found to be weaker or absent (Albaek et al., 2000; Daouli et al., 2013; Blien et al., 2013; von Fintel, 2015).

On the other hand, the line of causality may run in the opposite direction, and is the primary objective of the current study: institutional bargaining may result in wage setting that is decoupled from worker productivity, making it unprofitable for firms to hire workers, and consequently raises the unemployment rate (Fedderke, 2012; Klein, 2012; Magruder, 2012). In this case wages and unemployment rates would be positively related, as opposed to the negative coefficient implied by the wage curve theory. Hence, simply studying the correlation between wages and unemployment can be misleading, as the causal estimates in one direction or the other could have opposite signs and interpretations.

While the wage curve literature has proposed methods to separate the simultaneous processes from each other through the use of instrumental variables (Baltagi et al., 2012), few micro-econometric studies have sought to interrogate the causal influence that wages exert on unemployment. This study proposes to fill this gap in a context where many commentators and authors allege that inflated wage demands constitute a partial explanation for high unemployment rates. In particular, South Africa's economy is characterized by high degrees of labour bargaining, wage growth that often outstrips productivity growth and high unemployment (Klein, 2012; Wakeford, 2004). The question is whether these stylized facts are causally interrelated, or co-incidentally correlated. While many authors have shown that collective bargaining and unionization is successful at raising wages in South Africa (Magruder, 2012; Armstrong \& Steenkamp, 2008; Hofmeyr \& Lucas, 2002; Bhorat et al., 2012), Bhorat et al. (2014) contend that the effects of unions have generally been benign when judged in light of the international context. Despite successive downgrades from rating agencies in 2014 and 2015 
(in part following on from large-scale industrial action), South Africa's strike intensity and union wage premia are not higher than comparable economies; however, its high unemployment rate remains an outlier. It is therefore not immediately clear that bargaining mechanisms directly contribute to high unemployment, or that bargaining can explain the full extent of unemployment, as acknowledged by Magruder (2012). We investigate the veracity of these claims.

However, should the argument (that the union premium distorts the wageproductivity link) nevertheless hold true, it implies that wage growth among better-paid unionised workers should have a greater negative effect on labour demand than those of poorly paid non-unionised workers. Sectoral and macro studies typically investigate the effects of average wages on employment, which in most countries represents the lowest part of the remuneration distribution $^{4}$. To more explicitly test the differential effects of unskilled and highly skilled workers in a market with structural employment, this paper exploits the micro data to study the effects of changes in wages - at different points in the distribution - on labour market outcomes. It distinguishes between the case where changes in wages at the middle to top of the distribution - which are typically set by unions or collective bargaining agreements - raise unemployment and the case where changes in wages at the bottom of the distribution (outside of the bargaining environment) have a defining role to play.

\subsection{Wages and labour supply}

Typically labour supply elasticities using micro data relate individuals' hours worked to the wages they are offered. Evers et al. (2008) provide a recent review of this extensive literature. Empirically the main problems in estimating these elasticities are endogeneity and the selection bias that arises because the labour supplied (as measured by hours worked) of unemployed

\footnotetext{
${ }^{4}$ Wages are commonly known to be skewly distributed, following approximately lognormal and Pareto forms. This implies that the average lies considerably below the median. This is also true in South Africa (von Fintel, 2007).
} 
workers is not observed. Instrumental variables and Heckman selection models have been employed to solve these issues. Given the very high rate of unemployment in South Africa, we adapt the concept of labour supply to indicate whether individuals are willing to work at all (at the extensive margin) and not how long they are willing to work if they do have have a job. As discussed below, a specific instrumental variables' approach is followed, exploiting the time variation in the data at our disposal.

The meta-analysis of Evers et al. (2008), which covers a range of countries, suggests that for both men and women, labour supply elasticities are positive on average. This implies that both genders fall on a part of the labour supply curve where substitution effects dominate income effects, so that higher wages make work more attractive than leisure.

Despite this extensive international work, there is little focus on the influence of wage growth (in particular) on labour supply in the South African context, particularly differentiated by skill type. Instead, most authors have focused on the demographic drivers of labour force participation. It is quite likely, however, that wage increases attract otherwise non-participating individuals into the labour market (similarly to the international experience); these shifts have the potential to raise unemployment, especially if labour demand simultaneously slows down as a result of rising wages. Alternatively, if income effects dominate substitution effects, wage escalations could have a negative impact on labour force participation, though the effect may differ by household income levels. Individuals living in households with other high earners may choose to exit the labour market when their wages rise; on the other hand, if individuals live with low earners, wage growth may be an incentive to enter the labour market. Some existing evidence does suggest that individuals are unlikely to base their participation decisions on the (un)favourable labour market experiences of their own generation, but rather on those of their parents and grandparents (Rothkegel, 2013). Participation rates may, by inference, be only weakly related to current wage fluctuations 
faced by a particular peer group. However, the empirical evidence on this is limited in South Africa.

This paper therefore re-examines the assertion that wage-setting is an important driver of unemployment in South Africa: it turns to micro-level estimates of employment, participation and unemployment elasticities to understand whether changes in wages of the highly paid and low paid workers have the greatest effects at attracting individuals into the labour market, slowing down job creation.

\section{Estimation strategy using micro pseudopanel data}

Usually the relationship between wage levels and employment is estimated using sector-level time series data, with the focus on wage-employment elasticities. When this has been done in South Africa, the estimates are characteristically high and negative; indicating that rising labour costs outstrip productivity gains and, in turn, constrain employment growth (Fourie, 2011: 53-56; Fedderke, 2012). This tells a particular story of the labour market, whereby the causal chain runs from labour costs to labour demand, rather than subscribing to the wage curve literature which suggests that poor labour market conditions assist in tempering wage demands ${ }^{5}$. Firmlevel estimates of this sort also emphasise the great degree of elasticity of labour demand of all skill types with respect to rising labour costs (Behar, 2010).

This narrative, however, stands in contrast to household survey evidence, which implies a relatively small role for institutionalized wage setting (in terms of both collective bargaining and minimum wages) in reducing employment levels (Bhorat et al., 2014; Dinkelman \& Ranchhod, 2012; Bhorat

\footnotetext{
${ }^{5}$ In fact, recent research (Von Fintel, 2015) has questioned the existence of the short-run wage curve for South Africa: a lack of an effect of local unemployment rates on wages in micro data (in contrast to the robust relationship found between employment and wages in sectoral data) emphasizes the need to separately identify the bi-directional causal chains.
} 
et al., 2013). By definition, the use of sectoral or firm level data to estimate wage-employment elasticities limits the analysis to understanding issues of labour demand and how they relate to labour costs. Using household survey data will provide greater insight into how individual labour supply is related to labour costs, and in turn provides a key perspective to the unemployment puzzle. Importantly, growing labour supply that has not been matched by an expansion in employment, is now regarded as a dominant part of the unemployment trajectory in South Africa (Burger \& von Fintel, 2014; Banerjee et al., 2008; Branson \& Wittenberg, 2007)

Therefore, this paper seeks to combine these two perspectives in estimating the influence of wages on other labour market outcomes, both on the demand and supply side, using micro-level pseudopanel data collected from households. This turns away the attention from the impact of labour market conditions on wages, as investigated in earlier work (von Fintel, 2015). Household surveys contain information on individuals' choice to enter the labour market and, following that decision, their success in being absorbed into a job. As Burger \& von Fintel (2009) show, each of these outcomes contributes directly to the unemployment rate as follows:

$$
\begin{aligned}
& \text { unemployment rate }=1-\frac{e / p}{(e+u) /(e+u+p)} \\
& =1-\frac{\text { employment rate }}{\text { labour force participation rate }}
\end{aligned}
$$

where $e$ is the number of employed, $p$ is the population of working age, $u$ is the number of unemployed. These quantities can be computed for various demographic or spatial units within representative repeated cross section household surveys over time - something which is not usually possible with macro-level time series, sectoral panel or firm panel data. Such data aggregated for a defined spatial unit in various time periods from cross section 
surveys - constitutes a pseudo-panel ${ }^{6}$, which can be treated in much the same way as a conventional panel dataset if constructed from a sufficient number of underlying datapoints (Verbeek \& Nijman, 1992; Deaton, 1997; Deaton \& Paxon, 1994; McKenzie, 2006). We use the household survey data to construct a district panel.

The work of von Fintel (2015) identified boundaries of South Africa's 55 district councils as reasonable delineations of local labour market conditions. Hence, the labour market conditions of all individuals that live within this spatial unit are summarised: employment, labour force participation and unemployment rates, as well as wage percentiles, are constructed for each region. In particular, using the Labour Force Survey (LFS) of September 2000 through to the March 2004 round, we construct each quantity bi-annually, as it is possible to identify these demarcations in the micro data (Magruder, 2012). The map in Figure 1 shows the relevant districts, and also illustrates the distinct geographic variation in local unemployment rates across the country: labour markets are slacker in districts located in the densely populated former apartheid homelands than elsewhere. Each of these districts can be followed over time in the various rounds of the survey, allowing standard longitudinal analysis of local labour market outcomes; this is possible even if the same individuals are not sampled in each region over time, but if the surveys are constructed to be representative of this geographic unit. Each of the districts is large enough to contain sufficient individual observations in each round of the LFS to treat the regionally aggregate statistics over time as a pure panel dataset at the district level, so that conventional estimators will be applied to the data (Verbeek \& Nijman, 1992).

\footnotetext{
${ }^{6}$ This data is not a pure panel dataset, as it does not necessarily follow the same individuals over time. However, it follows the aggregate outcomes of a representative group of individuals that constitutes a chosen unit of measurement - be it a birth cohort or a spatial unit. Repeated cross sections can be aggregated in this manner to construct a pseudo-panel.

${ }^{7}$ While it is possible to break this analysis down further by race and gender, these possibilities are relegated to future research.
} 


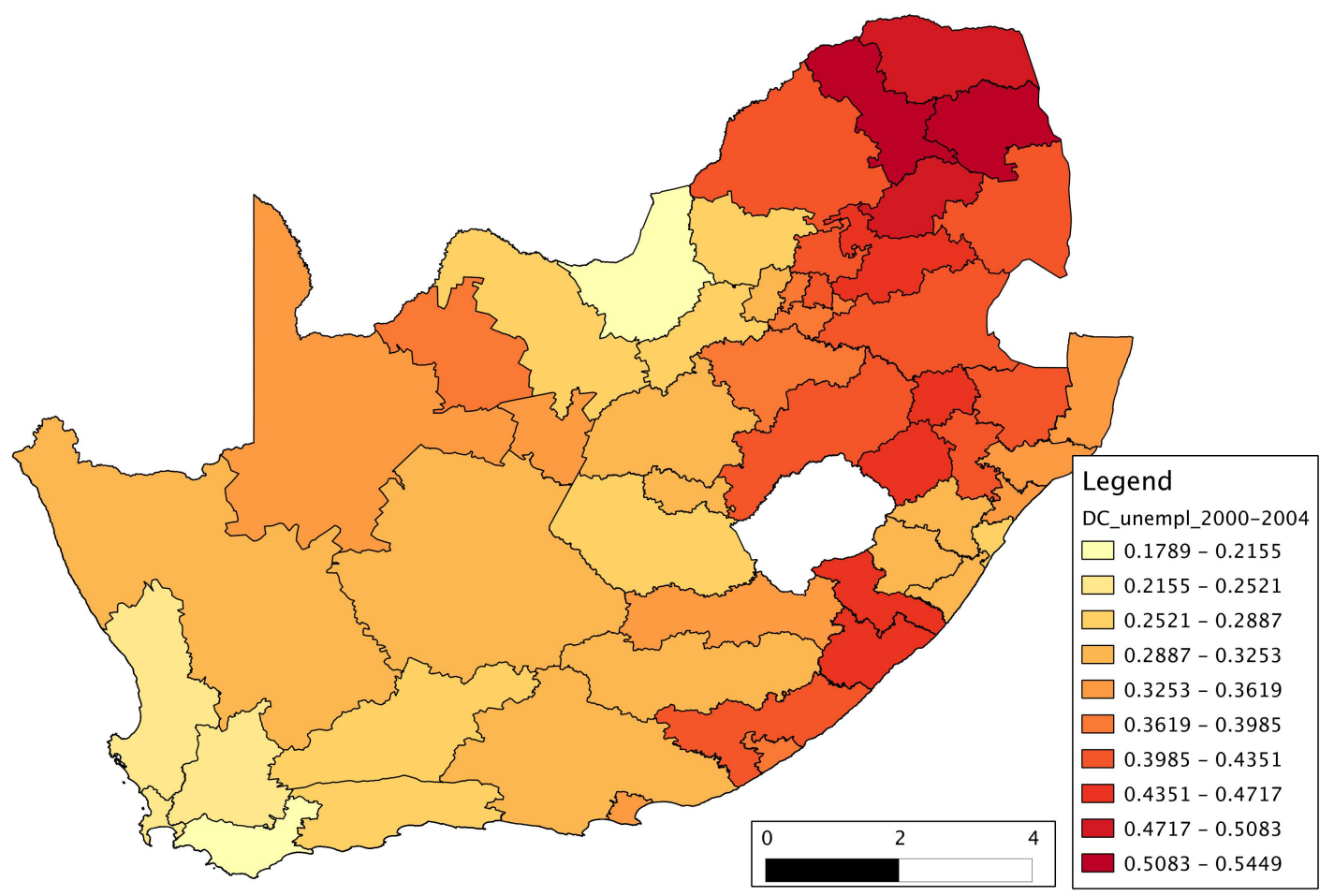

Figure 1 District council demarcations with broad unemployment rates pooled over time NOTES: Own calculations using LFS2000b to LFS 2004a.

These data are used to estimate functions of regional labour market conditions. The particular goal is to estimate the elasticity of each of these quantities in response to wage increases at various points along the distribution. The functional forms draw from a Cobb-Douglas specification, in which all variables are logged. However, unlike theory-driven specifications that control for time-variant capital costs and output (Fedderke \& Mariotti, 2002), data limitations entail the estimation of simpler, reduced form functions. Despite this deficiency, household data adds value in other dimensions: it enables the derivation of non-constant elasticites along various points of the wage distribution; additionally, the analysis of labour supply becomes possible. Controls for regional unobservables and the lag of the outcome ensure that coefficients measure short-run responses (net of persistence). The regional working-age population is introduced to control for variation in market size across district and the potentially confounding effects of migration across time. The specification can be expressed as: 


$$
\begin{aligned}
\log \left(y_{r ; t}\right)=\beta_{0} & +\beta_{1} \log \left(\text { wage percentile }_{r ; t}\right)+\beta_{2} \log \left(y_{r ; t-1}\right) \\
& +\beta_{3} \log \left(\text { population }_{r ; t}\right)+\gamma^{\prime} x+\mu_{r}+\varepsilon_{r t}
\end{aligned}
$$

where $r$ indexes regions and $t$ indexes time; $y$ is one of total regional employment, total number of labour force participants or total number of unemployed within a district. Wage percentiles are calculated for each district at various points in the distribution, in order to establish the sensitivity of labour market outcomes to changes in wages of various type of workers (high wage and low wage). We test whether low or high wages are influential in attracting individuals into the labour market, while simultaneously placing a constraint on labour demand, thereby resulting in wage-induced unemployment.

The elasticity of interest, $\beta_{1}$, is estimated along various points of the wage distribution and captures the sensitivity of labour supply and demand to rising labour costs. Because wages and outcomes are logged, the coefficient represents a percentage change in the labour market outcome, for a percentage change in the wage at a particular percentile. It can be estimated using various techniques. OLS estimates will be biased due to the simultaneity between wages and other labour market outcomes. Introducing fixed effects (as if the dataset is a usual panel) could bias estimates downwards if the measurement error that results from the aggregation process is severe. Also, this only accounts for spatial heterogeneity but does not eliminate reverse causality. On the other hand, if lagged dependent variables are included without necessary fixed effects to capture the true data generating process, estimates may also be downward biased (Angrist \& Pischke, 2009). Given these issues, we test the sensitivity of elasticity estimates to each of these identifying assumptions.

Instrumental variables may typically address the simultaneity bias, and time lags in particular (under the assumption that wages are predetermined) provide a potentially useful instrument for contemporaneous wages. The wage 
curve literature commonly uses lags of unemployment as instruments for contemporaneous unemployment (Baltagi et al., 2012; von Fintel, 2014). In a different approach, Falco et al. (2011) use dynamic panel data models to account for endogeneity in labour market equations, exploiting multiple moment conditions in the time lag structure of the independent variables by way of Generalised Method of Moments (GMM) estimators (Blundell \& Bond, 1998; Arrelano \& Bond, 1991). Instead of only implementing one lag as an instrument, a complex system of statistical moment restrictions between lagged variables and error terms are exploited to reduce simultaneity bias, account for permanent regional effects and control for persistence in labour market outcomes with a dynamic specification.

However, all dynamic panel data models are sensitive when the data contains a large number of time periods; the moment conditions that are imposed by GMM estimators expand multiplicatively with every extra wave of data. This results in overfitting of the endogenous variable with respect to the instrument set that is implied by the moment conditions. As a result, GMM estimates converge on OLS or fixed effects estimates, and the risk of endogeneity remains. Solutions to this problem are varied: one solution is to limit the lag length included in the instrument set; a second approach extracts principal components from the set of lagged differenced variables (Roodman, 2009). We follow the approach of limiting the lag length, estimating two-step GMM estimators.

\section{Results}

The discussion starts with an understanding of the effects of mean wages on local labour market conditions. Following this, a set of results across the entire distribution of wages is presented graphically, but without highlighting a full set of coefficients. This contribution highlights whether income or substitution effects in participation dominate at different parts of the wage distribution (in other words, whether participation rates increase or decrease in response to wage increases), and whether low paying or high paying jobs 
play a greater role in constraining employment growth. In this section we also explicitly consider whether behaviour is driven by the union wage premium in certain parts of the wage distribution, and - indirectly - whether bargaining council arrangements play a role.

\subsection{Employment elasticities}

Estimates of wage-employment elasticities are shown in the first row of Table 1. The pooled OLS approach in column 1 accounts for none of the potential estimation biases discussed in section 2. The method delivers a statistically insignificant negative elasticity and contrasts somewhat with sectoral evidence, which usually finds large negative and significant elasticities.

Fixed effects estimates in specification 2 control for permanent regional heterogeneity, raising the elasticity to a larger negative and significant effect. Nevertheless, the size of the coefficient remains relatively modest in relation to previous studies. GMM system estimates in specification 3 adjust for both regional heterogeneity and additionally uses the lag structure of wages and unemployment to account for reverse causality. The estimate is larger in absolute value than was the case in the previous approaches, and indicates that a percentage increase in mean district wages reduces employment by a quarter of a percent. Nevertheless, the elasticity that accounts for all sources of bias remains lower than those found by sectoral studies of mean wages (Fourie, 2011: 53-56).

The GMM result is credible from a diagnostic perspective: the insignificant Hansen test statistic suggests that the moment conditions are not overidentified, so that each of the lagged instruments has an influence on reducing bias. Additionally, the pattern of significant first order autocorrelation in the error terms and zero second order autocorrelation conforms to the norms that are required for the consistency of the GMM 
estimator (Arrelano \& Bond, 1991). All GMM specifications in this paper satisfy these criteria.

Specifications 4 to 6 repeat the previous estimates, but control for districtlevel union density and the concentration of employment in small and large firms. These indicators proxy for wage bargaining institutions, which occur at the firm level and in bargaining councils between large firms and large unions (Magruder, 2012; Bhorat et al., 2012). Notably, the coefficient using the fixed effects estimator halves, and becomes slightly smaller and insignificant in the case of the GMM estimator. At least a part of the effect of wages on labour demand can be accounted for by wage escalations that result from these institutions 
Table 1 District Council Employment Models

\begin{tabular}{|c|c|c|c|c|c|c|}
\hline & 1 & 2 & 3 & 4 & 5 & 6 \\
\hline Dependent: $\log (\text { employment })_{d t}$ & Pooled OLS & $\mathrm{FE}$ & GMM-sys & Pooled OLS & $\mathrm{FE}$ & GMM-sys \\
\hline $\log ($ wage $)$ & -0.047 & $-0.248^{* * *}$ & $-0.257 * * *$ & -0.041 & $-0.118^{* *}$ & -0.243 \\
\hline $\log (e m p l)_{t-1}$ & $0.752^{* * *}$ & -0.019 & $0.597^{* * *}$ & $0.699 * * *$ & -0.028 & $0.476^{* * *}$ \\
\hline Primary & 0.383 & 0.000 & -0.698 & $0.472^{*}$ & 0.048 & 0.678 \\
\hline Incomplete Secondary & 0.059 & $-0.796^{* *}$ & -0.564 & 0.136 & $-0.640^{*}$ & 0.259 \\
\hline Matric & $1.125^{* * *}$ & 0.132 & $1.838^{*}$ & $1.160^{* * *}$ & 0.326 & $3.375^{* * *}$ \\
\hline Post-Secondary & $1.076^{* * *}$ & $1.871^{* * *}$ & 2.468 & $0.928^{* *}$ & $1.852^{* * *}$ & 3.577 \\
\hline $\log ($ population) & $0.231^{* * *}$ & $0.816^{* * *}$ & 0.277 & $0.301^{* * *}$ & $0.838^{* * *}$ & $0.377^{* *}$ \\
\hline Constant & -0.360 & 2.167 & $1.594^{*}$ & -0.449 & 1.580 & 1.361 \\
\hline R-squared & 0.971 & 0.232 & & 0.973 & 0.341 & \\
\hline $\mathrm{N}$ & 364 & 364 & 364 & 364 & 364 & 364 \\
\hline Hansen p-value & & & 0.453 & & & 0.312 \\
\hline $\mathrm{AR}(1) \mathrm{p}$-value & & & $0.019^{*}$ & & & $0.006^{* * *}$ \\
\hline $\mathrm{AR}(2) \mathrm{p}$-value & & & 0.342 & & & 0.728 \\
\hline Controls for firm and union density & $\mathrm{N}$ & $\mathrm{N}$ & $\mathrm{N}$ & $\mathrm{Y}$ & $\mathrm{Y}$ & $\mathrm{Y}$ \\
\hline
\end{tabular}

NOTES: ${ }^{*} \mathrm{p}<0.1^{* *} \mathrm{p}<0.05^{* * *} \mathrm{p}<0.01$. Own calculations from district council pseudopanel constructed from LFS2000b-LFS2004a 
Table 2 District Council Labour Force Participation and Unemployment Models

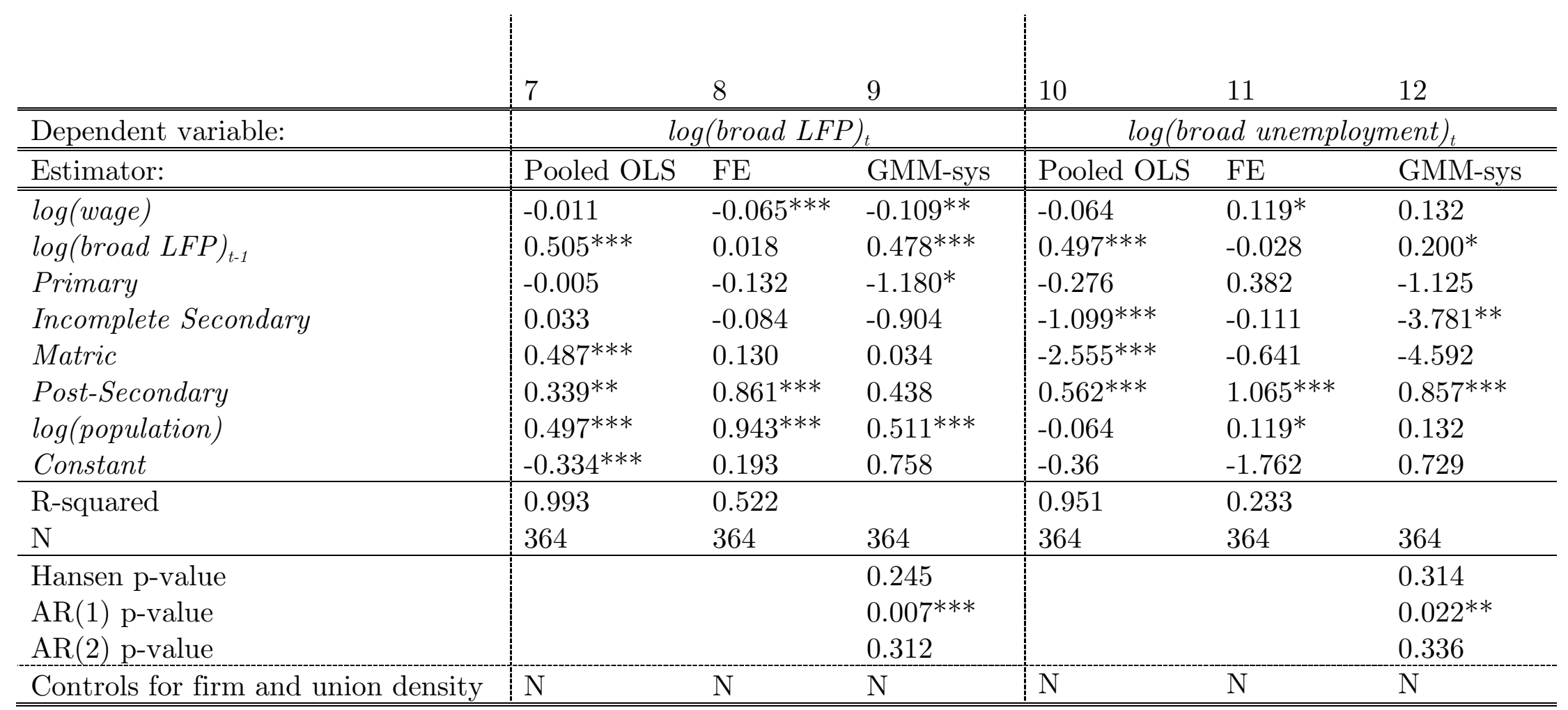

NOTES: ${ }^{*} \mathrm{p}<0.1 * * \mathrm{p}<0.05 * * * \mathrm{p}<0.01$. Own calculations from district council pseudopanel constructed from LFS2000b-LFS2004a. The broad definition of the labour market includes discouraged workers. 


\subsection{Participation elasticities}

Specifications 7 to 9 in Table 2 repeat these regressions, but this time considering only labour force participation. All elasticities are small in magnitude, regardless of estimation procedure, and de-emphasise the role of wages in driving the rise in labour force participation and, in turn, unemployment. Instead, it appears that income effects dominate substitution effects in labour force participation, with income gains of other household members prompting some exit from the labour market.

\subsection{Unemployment elasticities}

Specifications 10 to 12 turn to the effect of wages on unemployment, which is the outcome of both the demand and supply effects. OLS results again deliver insignificant elasticities, while accounting for fixed effects leads to a large positive unemployment elasticity that is also statistically significant. GMM estimates are similar in magnitude to fixed effects estimates, though not significant. While we do not observe a pattern by which wage growth increases labour supply (and in turn raises unemployment), the labour demand channel dominates in contributing to unemployment.

\subsection{Non-constant elasticities}

Up to now the discussion has focused on mean wages. However, these estimates ignore the fact that wage increases along different points of the distribution may have heterogeneous impacts on labour market incentives. Figure 2 summarises the set of elasticities from various estimators. The first row of figures represents coefficients from specifications that have the same set of control variables as specifications 1-3 and 7-12, while the second row shows elasticities that additionally condition on union density and the firm size structure of districts. 

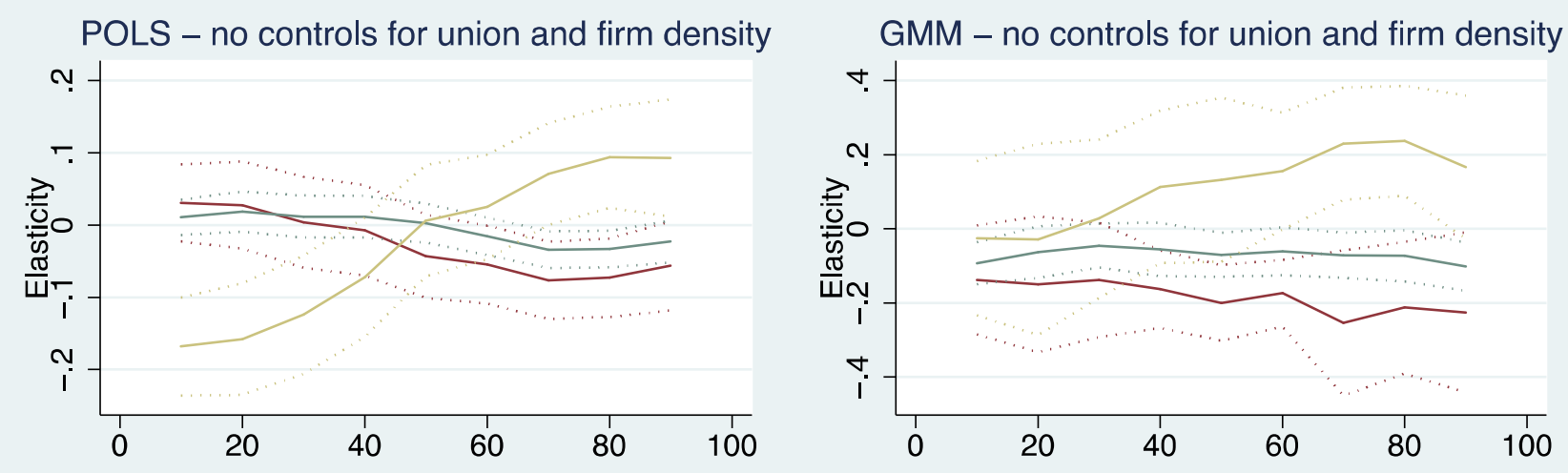

POLS - controlling for union and firm density

GMM - controlling for union and firm density
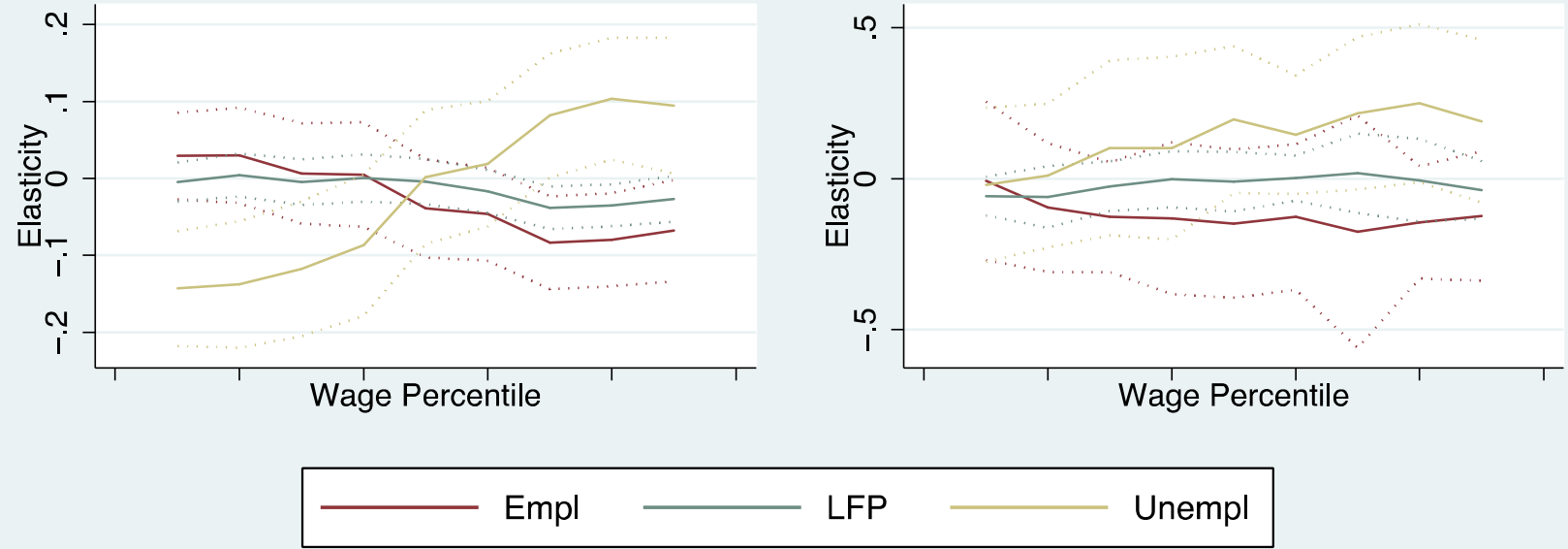

Figure 2 Employment, LFP and unemployment elasticities along the wage distribution using various estimators

NOTES: Elasticities with 95\% confidence intervals. Own calculations using LFS2000b to LFS 2004a. Estimates conducted along various points of the district council wage distribution. GMM system estimates use a two-step procedure, and limit the lag length in the moment conditions to 3. 
Wage-employment elasticities estimated by OLS are only statistically significantly different from zero above the $60^{\text {th }}$ percentile, while in the case of GMM, they become significant from the $30^{\text {th }}$ percentile. The introduction of union and firm size controls only influences GMM estimates, yielding a zero effect at all percentiles. Together, these results suggest that reductions in labour demand occur due to increases in wages in the middle to top of the wage distribution, and not at the very bottom, as time series evidence from the 1970-1990s would suggest (Lewis, 2001). Further, the causal GMM estimates indicate that employment reductions are particularly attributed to wage growth in districts with high union densities and with high concentrations of large firms.

Wage-participation elasticities are small and insignificant across most of the wage distribution, regardless of the estimation strategy. If anything, they are marginally significant in higher tails of the wage distribution, indicating that small income effects do arise. Demand-side effects dominate in determining unemployment, regardless of whether wages of high paid or low paid workers change.

Finally, wage-unemployment elasticities estimated by OLS are close to -0.1 in the lower tail of the wage distribution. This reflects the standard wage curve magnitude estimated by many researchers; such an effect is dominated by changes in wages of low earners. However, as found by von Fintel (2015), accounting for regional heterogeneity and reverse causality by GMM, the effect is reduced to zero at the bottom of the distribution. Mirroring the employment elasticities, unemployment responds to growth in wages at the middle to top of the distribution. Again, controls for unionization and firm sizes reduces GMM elasticities to zero, emphasising that the high wages that contribute to unemployment are in turn determined by institutional bargaining arrangements. 


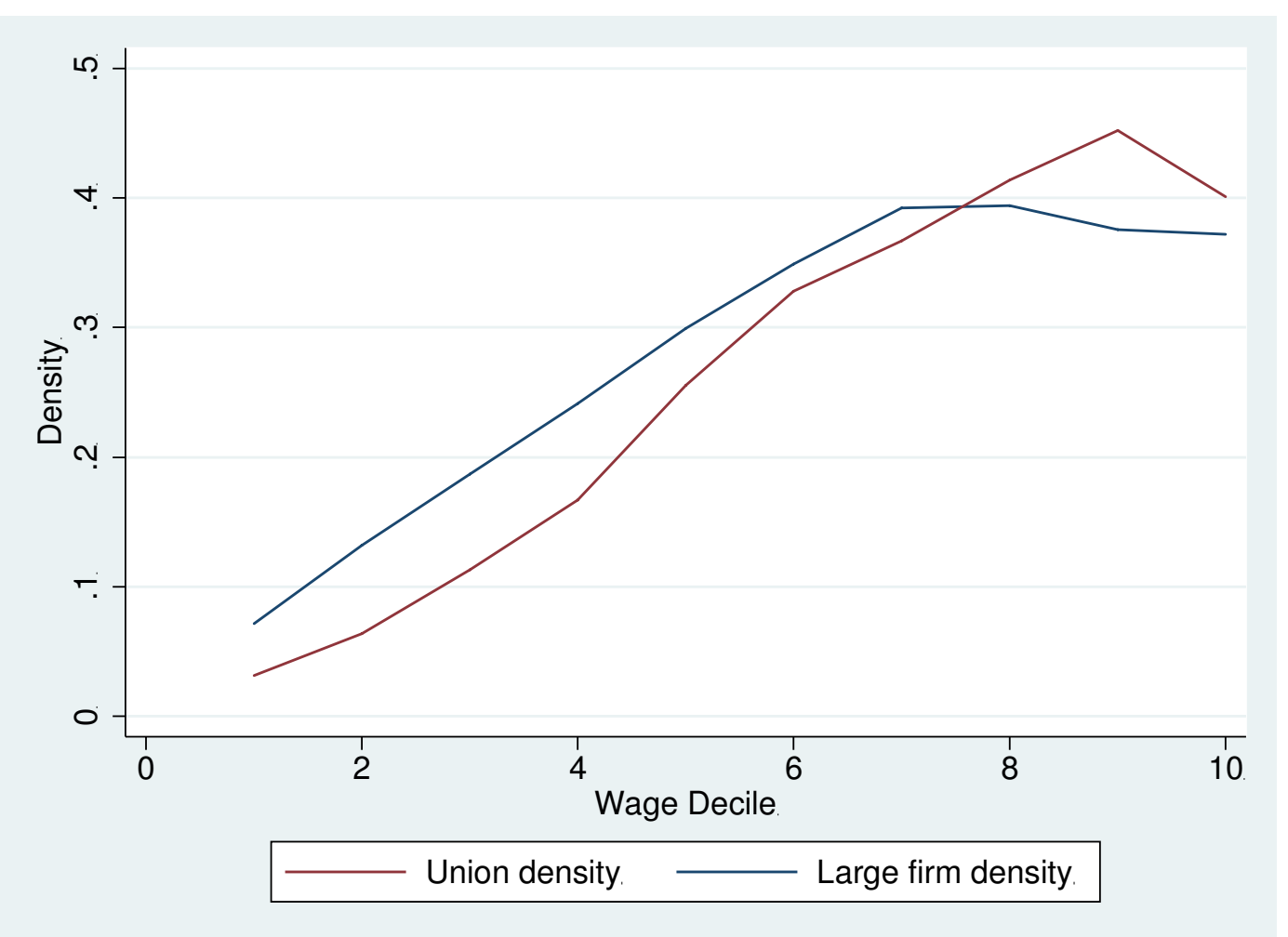

Figure 3 Union and Firm Size Density, by wage decile

NOTES: Wage deciles constructed by district council in each period. Data from LFS2000b to $2004 \mathrm{a}$ is pooled. Large firm is defined as a firm employing 50 or more individuals.

What could explain the heterogeneity of the employment and unemployment elasticities? Previous evidence on wage-setting shows that collective bargaining inhibits labour demand, and particularly so in small firms (Magruder, 2012; Rankin, 2016). Figure 3 shows both district-level union density and large firm density (defined as a firm with more than 50 employees) along the wage distribution. While both indicators rise with wages, the steepest incline for union density is in the middle of the distribution, with a decline at the very highest end. Similarly, large firm density rises steadily, but flattens off from the seventh wage decile. Comparing this figure with the wage elasticities, they correspond with the evolution of GMM-sys estimates, whereby the wage-unemployment elasticity increases in a similar fashion to both unionization and firm size density. Unionization seems to correspond with wage increases and a larger labour demand response. 


\section{Conclusion}

While the macroeconomic literature has emphasized labour demand as the channel through which rising labour costs fuel the level of joblessness, microeconometricians have emphasized the supply side in understanding unemployment in South Africa. This study has turned to both sides of this debate, by estimating the elasticity of various labour market outcomes to district level wages. It confirms that primarily labour demand is affected by wages, while labour supply is not as sensitive to the allure of better remuneration for workers. This does not abstract from the important role that expanding labour supply has had in rising unemployment in South Africa. It does, however, suggest that this did not occur through increases in wages, but rather by way of other demographic changes. Wages do, however, exert substantial influence on firms' choice to expand employment, confirming some previous results. This is particularly true for workers that earn median and above wages, where various estimates do show that unemployment increases in response to their wages.

The evidence also suggests that the channel through which these changes operate is high concentrations of unionized workers and employment in large firms (which typically bargain collectively). While this research does not claim to understand all features of high unemployment in South Africa, it does highlight how labour costs play a causal contributing factor in keeping its level elevated. It contrasts with evidence which suggests that institutionalized wage setting does not have uncharacteristic influences on labour demand (Bhorat et al., 2014; Bhorat et al., 2013), while it falls more closely in line with other work that highlights the role of unions and collective bargaining in inhibiting employment creation (Magruder, 2012; Rankin, 2016). This is not to say that non-unionised, low paid workers' wages can be raised without costs to employment; it is potentially true that once similar conditions (such as the proposed national minimum wage legislation) are applied to such workers, that similar effects could potentially manifest. These eventualities require continued rigorous investigation. 


\section{References}

Albaek, K. et al., 2000. Dimensions of the wage-unemployment relationship in the nordic countries: wage flexibility without wage curve. In S.W. Polachek, ed. Worker Well-being - Research in Labour Economics. pp.345-81.

Altonji, J.G. \& Devereux, P.J., 1999. The extent and consequences of downward nominal wage rigidity. NBER working paper 7236 .

Cambridge: National Bureau of Economic Research.

Angrist, J. \& Pischke, J.-S., 2009. Mostly Harmless Econometrics - An Empiricist's Companion. Princeton, New Jersey: Princeton University Press.

Armstrong, P. \& Steenkamp, J., 2008. South African Trade Unions: an Overview for 1995 to 2005. Stellenbosch Economic Working Paper $10 / 08$.

Arrelano, M. \& Bond, S., 1991. Some tests of specification for panel data: Monte Carlo evidence and an application to employment equations. Review of Economic Studies, 58, pp.277-97.

Baltagi, B.H., Baskaya, Y.S. \& Hulagu, T., 2012. The Turkish wage curve: Evidence from the Household Labor Force Survey. Economics Letters, 114(1), pp.128-31.

Banerjee, A. et al., 2008. Why has unemployment risen in the New South Africa? Economics of Transition, 16(4), pp.715-40.

Barattieri, A., Basu, S., \& Gottschalk, P., 2014. Some Evidence on the Importance of Sticky Wages. American Economic Journal: Macroeconomics, 6(1): 70-101.

Behar, A., 2010. Would cheaper capital replace labour? South African Journal of Economics, 78(2), pp.131-50.

Bhorat, H. \& Hodge, J., 1999. Decomposing Shifts in Labour Demand in South Africa. The South African Journal of Economics, 67(3), pp.34980 .

Bhorat, H., Goga, S. \& van der Westhuizen, C., 2012. Institutional wage effects: revisiting union and bargaining council wage premia in South Africa. South African Journal of Economics, 80(3), pp.400-14.

Bhorat, H., Mayet, N. \& Kanbur, R., 2013. The impact of sectoral minimum wage laws on employment, wages, and hours of work in South Africa. IZA Journal of Labor and Development, 2(1).

Bhorat, H., Naidoo, K. \& Yu, D., 2014. Trade unions in an emerging economy - the case of South Africa. WIDER Working Paper 2014/055. Helsinki: United Nations University - World Institute for Development Economics Research.

Blanchflower, D.G. \& Oswald, A.J., 1990. The Wage Curve. NBER Working Paper, 3181. 
Blanchflower, D.G. \& Oswald, A.J., 2008. Wage Curve. In S.N. Durlauf \& L.E. Blume, eds. The New Palgrave Dictionary of Economics. 2nd ed. Palgrave Macmillan.

Blien, U., Dauth, W., Schank, T. \& Schnabel, C., 2013. The Institutional Context of an 'Empirical Law': TheWage Curve under Different Regimes of Collective Bargaining. British Journal of Industrial Relations, 51(1), pp.59-79.

Blundell, R. \& Bond, S., 1998. Initial conditions and moment restrictions in dynamic panel data models. Journal of Econometrics, 87, pp.115-43.

Branson, N. \& Wittenberg, M., 2007. The measurement of employment status in South Africa using cohort analysis, 1994-2004. South African Journal of Economics, 75(2), pp.313-26.

Burger, R.P. \& von Fintel, D.P., 2009. Determining the Causes of the Rising South African Unemployment Rate: An Age, Period and Generational Analysis. Working Paper 158. Cape Town: Economic Research Southern Africa.

Burger, R.P. \& von Fintel, D.P., 2014. Rising unemployment in a growing economy: a business cycle, generational and life cycle persepective of post-transition South Africa's labour market. Studies in Economics and Econometrics, 38(1).

Burger, R.P., van der Berg, S. \& von Fintel, D.P., 2015. The unintended consequences of education policies on South African participation and unemployment. South African Journal of Economics, 83(1).

Casale, D. \& Posel, D., 2002. The continued feminisation of the labour force in South Africa: an analysis of recent data and trends. The South African Journal of Economics, 70(1), pp.156-84.

Daouli, J., Demoussis, M., Giannakopoulos, N. \& Laliotis, I., 2013. The wage curve during the great depression in Greece. Bonn, 22-23 August: 8th IZA/World Bank Conference on Employment and Development.

Deaton, A. \& Paxon, C., 1994. Saving, growth and aging in Taiwan. In D.A. Wise, ed. Studies in the Economics of Aging. Chicago: University of Chicago Press. pp.331-62.

Deaton, A., 1997. The analysis of household surveys: a microeconometric approach to development policy. Baltimore: Johns Hopkins University Press.

Dinkelman, T. \& Ranchhod, V., 2012. Evidence on the impact of minimum wage laws in an informal sector: Domestic workers in South Africa. Journal of Development Economics, 99(1): 27-45.

Evers, M., de Mooij, R. \& van Vuuren, D., 2008. The wage elasticity of labour supply: a synthesis of empirical estimates. De Economist. 156, pp.25-43.

Falco, P. et al., 2011. The returns to formality and informality in urban Africa. Labour Economics, 18, pp.S23-32.

Fedderke, J. \& Mariotti, M., 2002. Changing labour market conditions in South Africa: a sectoral analysis of the period 1970 - 1997. South African Journal of Economics, 70(5), pp.830-864.

Fedderke, J., 2012. The Cost of Rigidity: the case of the South African labor market.Comparative Economic Studies, 54. 
Fourie, F.C.V.N., 2011. The South African unemployment debate: three worlds, three discourses? SALDRU Working Paper 63. Cape Town: University of Cape Town.

Hofmeyr, J.F. \& Lucas, R.E.B., 2002. The Rise in Union Wage Premiums in South Africa. Labour, 15(4), pp.685-719.

Klein, N., 2012. Real Wage, Labor Productivity, and Employment Trends in South Africa: A Closer Look. IMF Working Paper 12/92. Washington, DC: International Monetary Fund.

Levinsohn, J., Rankin, N., Roberts, G. \& Schoer, V., 2014. Wage subsidies and youth employment in South Africa: Evidence from a randomised control trial. Stellenbosch Economic Working Paper 02/14. University of Stellenbosch.

Lewis, J.D., 2001. World Bank Informal Discussion Paper on Aspects of the Economy of South Africa 16.

Magruder, J., 2012. High Unemployment Yet Few Small Firms: The Role of Centralized Bargaining in South Africa. American Economic Journal: Applied Economics, 4(3), pp.138-66.

McKenzie, D., 2006. Disentangling age, cohort and time effects in the additive model. Oxford Bulletin of Economics and Statistics, 68(4), pp.473-95.

Ranchhod, V. \& Finn, A., 2014. Estimating the short run effects of South Africa's Employment Tax Incentive on youth employment probabilities using a difference-in-differences approach. SALDRU Working Paper 134, Cape Town: Southern Africa Labour and Development Research Unit.

Rankin, N., 2016. Labour productivity, factor intensity and labour costs in South African manufacturing. REDI3x3 Working Paper, Cape Town, Research Project on Employment, Income Distribution and Inclusive Growth.

Roodman, D., 2009. A Note on the Theme of Too Many Instruments. Oxford Bulletin of Economics and Statistics, 71(1), pp.135-58.

Rothkegel, M., 2013. Generational Returns to Education. Mimeograph, Stellenbosch University.

Verbeek, M. \& Nijman, T., 1992. Can cohort data be treated as genuine panel data? Empirical Economics, 17, pp.9-23.

Von Fintel, D.P., 2007. Dealing with earnings bracket responses in household surveys - how sharp are midpoint imputations? South African Journal of Economics, 75(2), pp. 293-312.

Von Fintel, D.P., 2015. Wage flexibility in a high unemployment regime: spatial heterogeneity and the size of local labour markets. REDI3x3 Working Paper 8: Cape Town, Research Project on Employment, Income Distribution and Inclusive Growth.

Wakeford, J., 2004. The productivity-wage relationship in South Africa: an empirical investigation. Development Southern Africa, 21(1): 109-132. 